\title{
PENGARUH MOTIVASI KERJA TERHADAP KINERJA KARYAWAN PADA PT. PUTRA MULIA TELECOMMUNICATION SELAMA MEMBERLAKUKAN WFH (WROK FROM HOME)
}

\author{
Muhamad Abid', Abdul Rahman Safiih ${ }^{2}$ \\ Fakultas Ekonomi, Universitas Pamulang \\ Email: dosen02466@unpam.ac.id ${ }^{1}$,dosen02457@unpam.ac.id ${ }^{2}$
}

\begin{abstract}
Purpose. This study aims to determine how much influence motivation has on employee performance during the WFH (Work From Home) system at PT Putra Mulia Telecommunication.

Methods. The research method used in this study is descriptive, while the data processing method is quantitative, the sample determination method uses a saturated sample of 33 existing populations who are all respondents, the data collection method uses a questionnaire (questionnaire) and the data analysis method uses a validity test, reliability test, product-moment correlation coefficient test, coefficient of determination or determinant coefficient, and hypothetical and operational tests of research variables using independent variables (independent variables), namely motivation and dependent variable (variable dependent), namely employee performance. The population and sample in this study were employees of PT Putra Mulia Telecommunication Jakarta.
\end{abstract}

Findings. The results showed that there was a significant influence between motivation $(X)$ on performance $(Y)$. This is indicated by the count value of Motivation Variable $(X)$ on Performance $(Y)$ of count 41,918 > ttable 1,695. or Sig $0.000<0.05$ Then Ho is rejected and $\mathrm{Ha}$ is accepted meaning that there is a significant influence between Motivation $(X)$ on Performance ( $Y$ ). The level of relationship between Motivation $(X)$ and Performance $(Y)$ is 0.002, which means that Motivation $(X)$ has a not too strong relationship with Performance $(Y)$. and that the ability of the Performance Variable $(Y)$ is influenced by the Motivation Variable $(X)$ by $0.2 \%$, while $99.8 \%$ is the influence of other variables not examined in this study.

Implication. Companies should always carry out maximum control functions to ensure employee performance when employees work with the WFH (Work From Home) system so that employee performance can be as good as employees work with the WFO (Work From Office) system.

Keywords. Motivation, Employee Performance.

\begin{abstract}
ABSTRAK
Tujuan. Penelitian ini bertujuan untuk mengentahui seberapa besar pengaruh motivasi terhadap kinerja karyawan selama sistem kerja WFH (Work From Home), di PT Putra Mulia Telecommunication.

Metode. Metode penelitian yang dipergunakan dalam penelitian ini adalah metode deskriptif, sedangkan metode pengolahan data bersifat kuantitatif, metode penentuan sample menggunakan sampel jenuh sebanyak 33 populasi yang ada seluruhnya menjadi responden, metode pengumpulan data menggunakan penyebaran kuesioner (angket) dan
\end{abstract}


metode analisi data menggunakan uji validitas, uji reabilitas, uji koefisien korelasi product moment, uji koefisien determinasi atau koefisien penentu, dan uji hipotis dan operasional variabel peneliti menggunakan variabel bebas (variable indevenden) yaitu motivasi dan variabel terikat (variable devendent) yaitu kinerja karyawan. Populasi dan sampel dalam penelitian ini adalah karyawan PT Putra Mulia Telecommunication Jakarta.

Hasil. Hasil penelitian menunjukkan terdapat pengaruh signifikan antara Motivasi (X) terhadap Kinerja (Y). Hal ini ditunjukan dengan nilai thitung Variabel Motivasi (X) terhadap Kinerja (Y) sebesar thitung $41.918>$ ttabel 1.695 atau Sig $0.000<0.05$ Maka Ho ditolak dan Ha diterima artinya terdapat pengaruh signifikan antara Motivasi (X) terhadap Kinerja (Y). Tingkat hubungan Motivasi (X) terhadap Kinerja (Y) sebesar 0.002 artinya Motivasi (X) memiliki tingkat hubungan yang tidak terlalu kuat terhadap Kinerja (Y). Dan bahwa kemampuan Variabel Kinerja (Y) dipengaruhi oleh Variabel Motivasi (X) sebesar $0.2 \%$ saja sedangkan $99.8 \%$ merupakan pengaruh dari variabel lain yang tidak di teliti dalam penelitian ini.

Implikasi. Perusahaan hendaknya selalu melakukan fungsi control yang maksimal untuk memastikan Kinerja karyawan ketika karyawannya bekerja dengan sistem WFH (Wrok From Home) agar kinerja karyawan bisa sama baiknya seperti karyawan bekerja dengan sistem WFO (Wrok From Office).

\section{Kata Kunci : Motivasi, Kinerja}

\section{Pendahuluan}

Dunia saat ini sedang digemparkan dengan adanya virus baru yang berasal dari Kota Wuhan, Tiongkok. Virus covid-19 atau lebih dikenal dengan virus corona mulai menjadi momok menyeramkan bagi masyarakat terutama masyarakat China pada akhir tahun lalu. Virus ini mulai memasuki Indonesia pada pertengahan bulan Maret. World Health Organization (WHO) akhirnya menetapkan kejadian ini sebagai pandemi setelah 114 negata tercatat memiliki kasus virus ini. Dikutip dari CNN Indonesia,(21/3/2020) di Indonesia dalam kurun waktu kurang dari satu bulan saja sudah ada 450 orang positif terjangkit virus covid-19 dengan jumlah kematian 38 orang dan yang dinyatakan sembuh sebanyak 20 orang. WHO memberikan pernyataan bahwa penularan virus corona terjadi melalui kontak langung seperti sekresi dari orang yang terinfeksi, misalnya air liur, melalui droplet atau percikan pernapasan saat orang yang terinfeksi batuk, bersin, berbicara, atau bernyanyi. Kontak langsung adalah seseorang yang melakukan kontak fisik atau berada di 1 ruangan dalam jarak 1 meter dengan kasus PDP atau Positif Covid-19. Selain itu, kontak tidak langsung yang melibatkan benda atau permukaan yang terkontaminasi juga kemungkinan dapat menularkan virus. Terbaru, WHO menyatakan virus corona SARS-CoV-2 penyebab Covid-19 bisa menular lewat udara atau airborne. Transmisi melalui udara WHO resmi menyatakan bahwa penularan bisa terjadi melalui udara. Dalam pernyataan resminya, WHO mendefinisikan penularan melalui udara sebagai penyebaran agen penular yang disebabkan oleh penyebaran aerosol yang melayang di udara dalam jarak dan waktu yang lama.

Hal ini membuat pemerintah Indonesia harus mengambil langkah cepat untuk menekan penyebaran virus covid-19 ini. Langkah yang diambil oleh pemerintah adalah dengan melakukan social distancing kepada masyarakat dimana kebijakan ini diharapkan akan meminimalisir penyebaran virus covid-19, kemudian juga dikeluarkannya Peraturan Pemerintah (PP) No. 21/2020 - Pembatasan Sosial Berskala Besar (PSBB) Dalam Rangka Percepatan Penanganan COVID-19 yang berdampak pada dunia bisnis, dimana dengan sangat terpaksa banyak perusahaan yang harus meruubah system kerjanya dari Work From Office (WFO) menjadi Work From Home (WFH), hal ini tentu saja mendapatkan respond an tanggapan beragam dari para pelaku usaha, tetapi demi mendukung upaya pemerintah dalam rangka pencegahan penyebaran covid-19 mau tidak mau perusahaan harus melakukan perubahan system kerja tersebut. 
WFH adalah singkatan dari work from home yang berarti bekerja dari rumah. Secara umum biasanya work from home diartikan dengan cara kerja karyawan yang berada di luar kantor. Entah dari rumah, dari cafe atau restoran sesuai dengan keinginan karyawan. Sistem kerja WFH memang memiliki fleksibilitas yang tinggi. Hal ini guna mendukung keseimbangan karyawan antara pekerjaan dan kehidupan. Saat ini WFH sedang menjadi solusi karena adanya wabah virus corona. Hal ini agar mengurangi risiko penularan virus corona dan keselamatan karyawan.

WFH yang diberlakukan oleh perusahaan pastinya membawa dampak positif dan negative, dampak positif seperti yang sudah di sampaikan menjadi solusi dalam mengurangi risiko penularan virus corona namun dampak negatifnya adalah adanya kebiasa baru yang harus dilakukan oleh karyawan yaitu dengan bekerja dari rumah, dengan lingkungan, suasana dan fasilitas yang berbeda dari biasanya hal tersebut pastinya akan mempengaruhi motivasi karyawan pada saat bekerja hal ini pastinya akan mempengaruhi kinerja karyawan tersebut seperti yang terjadi pada PT. Putra Mulia Telecommunication yang telah memberlakukan WFH bagi sebagian karyawannya selama pandemic covid-19, adanya beberapa permasalahan yang dihadapi oleh karyawan PT. Putra Mulia Telecommunication selama melakukan WFH adalah :

1) Terganggu oleh keluarga, karena karyawan bekerja dari rumah pastinya sauna rumah dengan banyaknya anggota keluarga seperti istri dan anak-anak akan membuat karyawan sulit berkonsentrasi, terkecuali di dalam rumah karyawan tersebut memiliki ruang kerja khusus, namun sepertinya jarang sekali karyawan yang mempunyai ruang kerj akhusus, biasnaya karyawan akan bekerja dari rumah di kamar pribadi, di ruang makan atau di ruang tamu.

2) Fasilitas kerja yang terbatas, salah satu fasilitas yang utama adalah jaringan internet, jika karyawan bekerja di office karyawan tidak permu memikirkan jaringan internet karena mungkin ada tim IT yang memastikan jaringan internet nya tersedia untuk karyawan bekerja, namun jika dirumah karyawan harus menggunakan kuota internet pribadi yang sangat dibengaruhi oleh kualitas signal provider yang ada di daerah tempat tinggal karyawan tersebut, jika jaringannya kurang baik maka dipastikan akan menghambat pekerjaan karyawan, kemudian juga fasilitas lainnya seperti mesin printer, computer atau laptop, dan juga telephon.

3) Jam kerja yang tidak menentu, jam kerja ketika WFH dengan WFO pastinya sangat berbeda, disaat WFO kita sudah jelas jam berapa masuk dan berapa istirahat dan jam berapa pulang, namun ketika WFH bias jadi sepanjang waktu bekerja atau sepanjang waktu istirahat, sulit dibedakannya mana jam kerja dan mana jam pribadi karena semua dilakukan ditempat yang sama pada waktu yang sama.

4) Minimnya control dari atasan, adalah salah satu permasalahan selanjutnya, biasanya atasan hanya akan mengtontrol pekerjaan melalui telephon, group whatsap atau meeting zoom, namun hal ini sangat berbda dengan suasana kerja WFO dimana atasan bisa sewaktu-waktu mendatangi meja kerja klaryawan untuk melakukan control.

5) Tingginya potensi pelanggaran yang dilakukan oleh karyawan adalah dampak selanjutnya ketika control sulit dilakukan maka potensi pelanggaran akan meningkat.

Berdasarkan beberapa permaslahan diatas penulis ingin menelitih lebih lanjut terkait

"pengaruh motivasi kerja terhadap kinerja karyawan pada PT. Putra Mulia Telecommunication selama memberlakukan WFH".

\section{Kajian Pustaka dan Hipotesis}

Motivasi. Motivasi menurut Frederick Herzberg dalam Robbins\& Judge (2008:208), "Hubungan seorang individu dengan pekerjaan adalah mendasar dan bahwa sikap individu terhadap pekerjaan bisa sangat baik menentukan keberhasilan atau kegagalan".

Herzberg memandang bahwa kepuasan kerja berasal dari keberadaan faktor intrinsik dan ketidakpuasan kerja berasal dari ke tidak beradaan faktor-faktor ekstrinsik. Faktor-faktor ekstrinsik (hygiene factors) meliputi: (1) Upah, (2) Kondisi kerja, (3) Keamanan kerja, (4) Status, (5) Prosedur perusahaan, (6) Mutu penyeliaan, (7) Mutu hubungan interpersonal antar 
sesama rekan kerja, atasan, dan bawahan. Sedangkan faktor intrinsik atau yang biasa disebut dengan motivators meliputi: (1) Pencapaian prestasi, (2) Pengakuan, (3) Tanggung Jawab, (4) Kemajuan, (5) Pekerjaan itu sendiri, (6) Kemungkinan berkembang. Tidak adanya kondisikondisi ini bukan berarti membuktikan kondisi sangat tidak puas. Tetapi jika ada, akan membentuk motivasi yang kuat yang menghasilkan prestasi kerja yang baik.

$\mathbf{H}_{1}$. Motivasi berpengaruh signifikan terhadap kinerja karyawan

Kinerja. Menurut Mangkunegara (2001:57), "Kinerja adalah hasil kerja secara kualitas dan kuantitas yang dapat dicapai oleh seseorang karyawan dalam melaksanakan tugas sesuai dengan tanggung jawab yang diberikannya". Rivai (2004:14), "Kinerja merupakan hasil atau tingkatan keberhasilan seseorang secara keseluruhan selama periode tertentu dalam melaksanakan tugas dibandingkan dengan standar hasil kerja, target atau sasaran atau kriteria yang telah ditentukan terlebih dahulu dan telah disepakati bersama". Dessler (2010:514), "Kinerja pegawai merupakan suatu catatan dari outcomes yang dihasilkan sesuai dengan fungsi pekerjaan secara spesifik atau aktifitas selam periode waktu tertentu". Kinerja pegawai diukur dengan menggunakan empat dimensi, yaitu: kualitas pekerjaan, kuantitas pekerjaan, kehadiran dan konservasi. Menurut Wilson Bangun (2012:231), "Kinerja adalah hasil pekerjaan yang dicapai berdasarkan persyaratan-persyaratan pekerjaan'.

Dari beberapa pengertiaan tersebut dapat disimpulkan, Kinerja adalah kesediaan seseorang atau kelompok orang untuk melakukan sesuatu kegiatan dan menyempurnakannya sesuai dengan tanggung jawabnya dengan hasil seperti yang diharapkan.

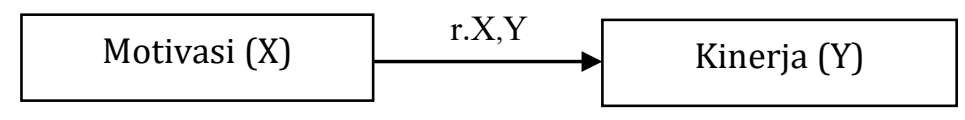

Gambar 1. Model Penelitian

\section{Metode Penelitian}

Pendekatan ini dilakukan dengan menggunakan pendekatan kuantitatif, dengan menggunakan metode study deskriiptif, yaitu metode yang diarahkan untuk memecahkan masalah dengan cara menerapkan atau menggambarkan apa adanya hasil penelitian. Ketepatan penentuan metode ini didasarkan pada pendapat Riduwan (2014:65). Bahwa aplikasi metode ini dimaksudkan untuk menyelidiki yang tertuju pada pemecahan yang ada pada masa sekarang. Pendapat yang sama dikemukakan oleh menurut Sugiyono (2014) merupakan salah satu metode dalam menganalisis data dengan menggambarkan data yang sudah dikumpulkan, tanpa membuat kesimpulan yang berlaku untuk umum (generalisasi). Pemilihan metode deskriptif dalam penelitian ini juga karena masalah yang sedang diteliti merupakan masalah yang sedang berlangsung di lingkungan PT Putra Mulia Telecommunication.

\section{Uji Instrumen Penelitian}

Dalam suatu penelitian, data mempunyai kedudukan yang sangat penting. Hal ini dikarenakan data merupakan penggambaran variabel yang diteliti dan berfungsi sebagai alat pembuktian hipotesis. Valid atau tidaknya data sangat menentukan kualitas dari data tersebut. Hal ini tergantung instrumen yang digunakan apakah sudah memenuhi asas validitas dan reliabilitas. Adapun dalam pengujian instrumen ini digunakan 2 (dua) pengujian yaitu validitas dan reliabilitas.

\section{Uji Asumsi Klasik}

Uji asumsi klasik digunakan untuk mengetahui ketepatan sebuah data. Menurut Santoso (2015:342) berpendapat "Sebuah model regresi akan digunakan untuk melakukan peramalan sebuah model yang baik adalah model dengan kesalahan peramalan yang seminimal mungkin. Karena itu, sebuah model sebelum digunakan seharusnya memenuhi beberapa asumsi, yang biasa disebut asumsi klasik". Dalam penelitian ini uji asumsi klasik yang 
digunakan: Uji Normalitas, Uji Multikolinearitas, Uji Autokorelasi, dan Uji Heterokedastisitas.

\section{Analisis Kuantitatif}

Analisis kuantitatif adalah penelitian untuk menilai kondisi dari nilai pengaruh, dan signifikansi pengaruh tersebut. Dalam penelitian ini analisis kuantitatif yang digunakan: Analisis Regresi Linier Sederhana, Linier Berganda, Analisis Koefisien Korelasi, Analisis Koefisien Determinasi, Pengujian Hipotesis.

\section{Hasil Penelitian dan Pembahasan Uji Validitas Instrumen}

Tabel 1 Hasil Uji Validitas Variabel Motivasi (X)

\begin{tabular}{|c|c|c|c|}
\hline & R-tabel & R-hitung & Keputusan \\
\hline Xi1 & 0.344 & 0.361 & Valid \\
\hline Xi2 & 0.344 & 0.361 & Valid \\
\hline Xi3 & 0.344 & 0.660 & Valid \\
\hline Xi4 & 0.344 & 0.677 & Valid \\
\hline Xi5 & 0.344 & 0.681 & Valid \\
\hline Xi6 & 0.344 & 0.670 & Valid \\
\hline Xi7 & 0.344 & 0.776 & Valid \\
\hline Xi8 & 0.344 & 0.776 & Valid \\
\hline Xi9 & 0.344 & 0.776 & Valid \\
\hline Xi10 & 0.344 & 0.776 & Valid \\
\hline Xi11 & 0.344 & 0.776 & Valid \\
\hline Xi12 & 0.344 & 0.588 & Valid \\
\hline Xi13 & 0.344 & 0.799 & Valid \\
\hline
\end{tabular}

Sumber : Data diolah (2021)

Tabel 2 Hasil Uji Validitas Variabel Kinerja (Y)

\begin{tabular}{|c|c|c|c|}
\hline & R-tabel & R-hitung & Keputusan \\
\hline Yi1 & 0.344 & 0.764 & Valid \\
\hline Yi2 & 0.344 & 0.787 & Valid \\
\hline Yi3 & 0.344 & 0.778 & Valid \\
\hline Yi4 & 0.344 & 0.792 & Valid \\
\hline Yi5 & 0.344 & 0.792 & Valid \\
\hline Yi6 & 0.344 & 0.792 & Valid \\
\hline Yi7 & 0.344 & 0.385 & Valid \\
\hline Yi8 & 0.344 & 0.385 & Valid \\
\hline Yi9 & 0.344 & 0.394 & Valid \\
\hline Yi10 & 0.344 & 0.394 & Valid \\
\hline Yi11 & 0.344 & 0.488 & Valid \\
\hline Yi12 & 0.344 & 0.478 & Valid \\
\hline Yi13 & 0.344 & 0.478 & Valid \\
\hline
\end{tabular}

Sumber : Data diolah (2021)

Berdasarkan data tabel di atas, variabel $\mathrm{X}$ dan $\mathrm{Y}$ diperoleh nilai $\mathrm{r}$ hitung $>\mathrm{r}$ tabel (0.344), dengan demikian maka semua item kuesioner dinyatakan valid. Untuk itu kuesioner yang digunakan layak untuk diolah sebagai data penelitian. 


\section{Uji Reliabilitas Instrumen}

Tabel 3 Hasil Uji Reliabilitas Variabel Independen dan Dependen

\begin{tabular}{|l|c|c|c|}
\hline \multicolumn{1}{|c|}{ Variabel } & Cronbatch Alpha & $\begin{array}{c}\text { Standar Cronbatch } \\
\text { Alpha }\end{array}$ & Keputusan \\
\hline Motivasi (X) & 0.756 & 0.600 & Reliabel \\
\hline Kinerja karyawan (Y) & 0.749 & 0.600 & Reliabel \\
\hline
\end{tabular}

Sumber : Data diolah (2021)

Berdasarkan hasil pengujian pada tabel di atas, menunjukkan bahwa variabel motivasi (X) dan kinerja karyawan (Y) dinyatakan reliabel, hal itu dibuktikan dengan masing-masing variabel memiliki nilai Chronbath Alpha lebih besar dari 0,600.

\section{Pengujian Asumsi Klasik (Uji Prasyarat Data)}

\section{Uji Normalitas}

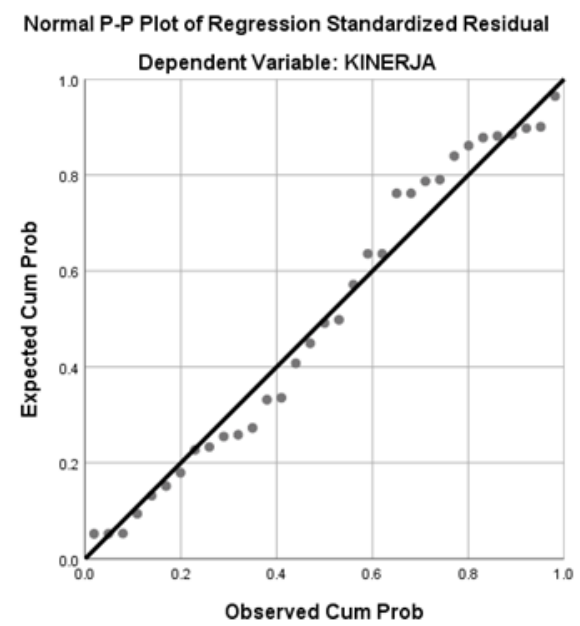

Gambar 2 Hasil Uji Normalitas

Sumber : Data diolah (2021)

Berdasarkan gambar di atas bahwa titi-titik menyebar disekitar garis dan mengikuti garis diagonal, artinya bahwa nilai residual yang dihasilkan dari regresi tersbut normal.

Uji Multikolinearitas

Tabel 4 Hasil Pengujian Multikolinearitas - VIF (Variance Inflation Factors)

\begin{tabular}{|c|c|c|}
\hline \multirow{2}{*}{ Variabel } & \multicolumn{2}{|c|}{ Colinerity Statistics } \\
\cline { 2 - 3 } & Tolerance & VIF \\
\hline Motivasi (X) & 1.000 & 1.000 \\
\hline
\end{tabular}

Sumber : Data diolah (2021)

Dari hasil output data didapatkan bahwa nilai VIF $<10$ dan nilai tolerance $>0,10$ maka tidak terjadi gejala Multikolinieritas. 


\section{Uji Heteroskedastisitas}

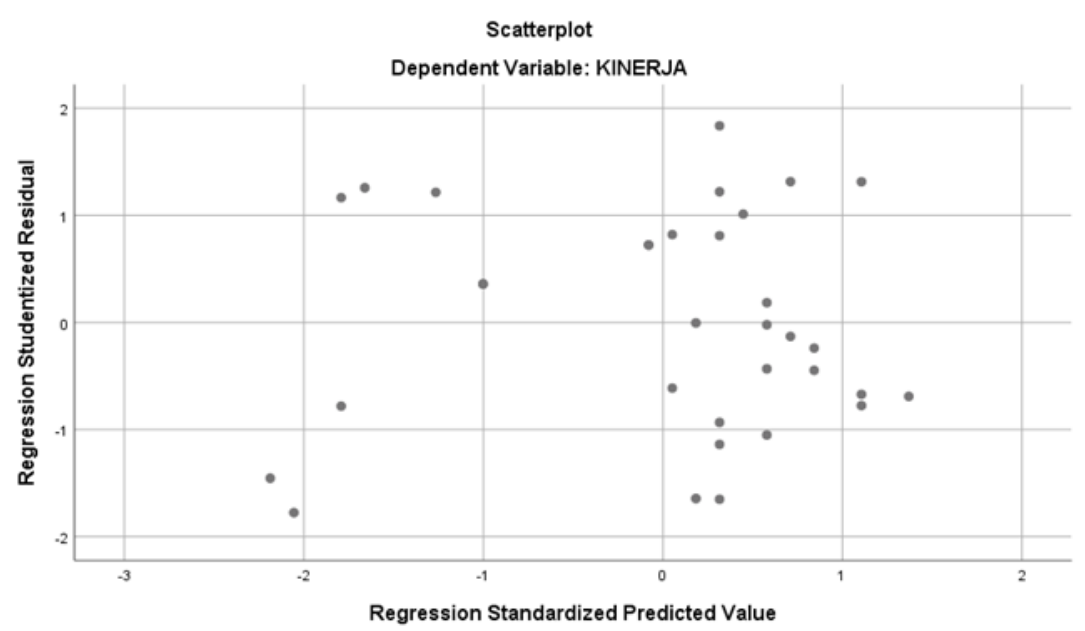

Gambar 3 Hasil Uji Heteroskedastisitas

Sumber : Data diolah (2021)

Dari output di atas kita dapat melihat bahwa titik-titik tidak membentuk pola yang jelas, dan titik-titik menyebar diatas dan dibawah angka 0 pada sumbu $Y$, jadi dapat disimpulkan tidak terjadi masalah Heterokedastisitas dalam model regresi.

\section{Analisis Kuantitatif \\ Regresi Linier Sederhana}

Tabel 5 Hasil Pengujian Regresi Linier Sederhana Variabel Motivasi $\left(\mathrm{X}_{1}\right)$ Terhadap Produktivitas karyawan (Y)

\begin{tabular}{|l|l|c|c|c|c|c|}
\hline \multicolumn{9}{|c|}{ Coefficientsa } \\
\hline \multirow{2}{*}{ Model } & \multicolumn{2}{|c|}{$\begin{array}{c}\text { Unstandardized } \\
\text { Coefficients }\end{array}$} & $\begin{array}{c}\text { Standardized } \\
\text { Coefficients }\end{array}$ & \multirow{2}{*}{$\mathrm{t}$} & \multirow{2}{*}{ Sig. } \\
\cline { 2 - 5 } & B & Std. Error & Beta & & \\
\hline \multirow{2}{*}{1} & (Constant) & 41.918 & 8.853 & & 4.735 & 0.000 \\
\cline { 2 - 6 } & Motivasi (X) & 0.055 & 0.231 & 0.042 & 0.236 & 0.815 \\
\hline \multicolumn{2}{|l|}{ a. Dependent Variable: Kinerja Karyawan (Y) } \\
\hline
\end{tabular}

Sumber : Data diolah (2021)

Berdasarkan hasil perhitungan regresi pada tabel di atas, maka dapat diperoleh persamaan regresi $Y=41,918+0,055 X$. Dari persamaan di atas maka dapat disimpulkan sebagai berikut:

a. Nilai konstanta sebesar 41,918 diartikan bahwa jika variabel motivasi (X) tidak ada maka telah terdapat nilai kinerja karyawan (Y) sebesar 41,918 point.

b. Nilai koefisien regresi motivasi (X) sebesar 0,055 yang artinya jika Variabel Motivasi (X) meningkat satu satuan, maka Kinerja (Y) akan meningkat sebesar 0.055.

\section{Analisis Koefisien Determinasi ( $R$ Square)}

Tabel 6 Hasil Analisis Koefisien Determinasi

\begin{tabular}{|l|c|c|c|c|}
\hline \multicolumn{5}{|c|}{ Model Summary } \\
\hline Model & $\mathrm{R}$ & $\begin{array}{c}\mathrm{R} \\
\text { Square }\end{array}$ & $\begin{array}{c}\text { Adjusted } \mathrm{R} \\
\text { Square }\end{array}$ & $\begin{array}{c}\text { Std. Error of the } \\
\text { Estimate }\end{array}$ \\
\hline 1 & $.042 \mathrm{a}$ & .002 & -.030 & 9.915 \\
\hline \multicolumn{2}{|l|}{ a. Predictors: (Constant), Motivasi (X) } \\
\hline
\end{tabular}

Sumber : Data diolah (2021) 
Berdasarkan tabel 6 diperoleh nilai R Square sebesar 0.002. hal ini menunjukan bahwa kemampuan Variabel Kinerja (Y) dipengaruhi oleh Variabel Motivasi (X) sebesar $0.2 \%$ sedangkan 99.8\% merupakan pengaruh dari variabel lain yang tidak di teliti dalam penelitian ini.

\section{Pengujian Hipotesis}

Tabel 7 Hasil Uji Hipotesis (Uji t) Variabel Motivasi $\left(\mathrm{X}_{1}\right)$ Terhadap Produktivitas karyawan $(\mathrm{Y})$

\begin{tabular}{|c|c|c|c|c|c|c|}
\hline \multicolumn{7}{|c|}{ Coefficients $^{\mathbf{a}}$} \\
\hline \multirow{2}{*}{ Model } & $\begin{array}{c}\text { Unstandardized } \\
\text { Coefficients }\end{array}$ & $\begin{array}{c}\text { Standardized } \\
\text { Coefficients }\end{array}$ & \multirow{2}{*}{$\mathrm{t}$} & \multirow{2}{*}{ Sig. } \\
\cline { 2 - 5 } & B & Std. Error & Beta & & \\
\hline \multirow{2}{*}{1} & (Constant) & 41.918 & 8.853 & & 4.735 & 0.000 \\
\cline { 2 - 6 } & Motivasi (X) & 0.055 & 0.231 & 0.042 & 0.236 & 0.815 \\
\hline \multicolumn{7}{|l|}{}
\end{tabular}

a. Dependent Variable: Kinerja Karyawan (Y)

Sumber : Data diolah (2021)

Berdasarkan tabel 7 diatas diperoleh hasil sebagai berikut : Nilai signifikansi (Sig) Variabel Motivasi (X) adalah sebesar 0.000 , karena nilai Sig. $0,000<$ probabilitas 0,05 dan Nilai thitung untuk variable Motivasi $4.735>$ ttabel 1.695, maka dapat disimpulkan H1 atau hipotesis pertama di terima, artinya ada pengaruh signifikan antara Motivasi terhadap Kinerja (Y).

\section{Pembahasan Penelitian}

Berdasarkan hasil penelitian, menunjukkan terdapat pengaruh signifikan antara Motivasi (X) terhadap Kinerja (Y). hal ini ditunjukan dengan nilai thitung Variabel Motivasi (X) terhadap Kinerja (Y) sebesar thitung $41.918>$ ttabel 1.695. atau Sig $0.000<0.05$ Maka Ho ditolak dan Ha diterima artinya terdapat pengaruh signifikan antara Motivasi $(X)$ terhadap Kinerja (Y). Tingkat hubungan Motivasi (X) terhadap Kinerja (Y) sebesar 0.002 artinya Motivasi $(X)$ memiliki tingkat hubungan yang tidak terlalu kuat terhadap Kinerja (Y). dan bahwa kemampuan Variabel Kinerja (Y) dipengaruhi oleh Variabel Motivasi (X) sebesar $0.2 \%$ saja sedangkan $99.8 \%$ merupakan pengaruh dari variabel lain yang tidak di teliti dalam penelitian ini.

\section{Kesimpulan}

Terdapat pengaruh signifikan antara Motivasi (X) terhadap Kinerja (Y). hal ini ditunjukan dengan nilai thitung Variabel Motivasi (X) terhadap Kinerja (Y) sebesar thitung $41.918>$ ttabel 1.695. atau Sig $0.000<0.05$ Maka Ho ditolak dan Ha diterima artinya terdapat pengaruh signifikan antara Motivasi (X) terhadap Kinerja (Y). Tingkat hubungan Motivasi (X) terhadap Kinerja $(\mathrm{Y})$ sebesar 0.002 artinya Motivasi $(\mathrm{X})$ memiliki tingkat hubungan yang tidak terlalu kuat terhadap Kinerja (Y). dan bahwa kemampuan Variabel Kinerja (Y) dipengaruhi oleh Variabel Motivasi (X) sebesar 0.2\% saja sedangkan 99.8\% merupakan pengaruh dari variabel lain yang tidak di teliti dalam penelitian ini.

\section{Daftar Pustaka}

Afin Murtie, (2012). Menciptakan SDM Berkuwalitas,. PT. Gelora Aksara Pratama. Jakarta

Agus Purwanto, Erwan dan Dyah Ratih Sulistyastuti, (2007), Metode Penelitian Kuantitatif, Untuk Admnisitrasi Publik, dan Masalah-masalah Sosial, Gaya Media Jogyakarta

Akrani, Gaurav. (2009). "Human Resource Management-Human Resource Development". Kailan City. www://httpkalyam city.blogspot.com200912 humanresour-management-human.html. 
Algifari. (2013). Statistika Induktif: untuk Ekonomi dan Bisnis. Yogyakarta: Sekolah Tinggi Ilmu Manajemen YKPN

Andriani, J., Sularmi, L., \& Anggraini, N. (2021). Pengaruh Lingkungan Kerja Dan Motivasi Terhadap Kinerja Karyawan Pada PT. Naga Mas Intipratama Tangerang. Jurnal Arastirma, 1(1), 43-54. Https://Doi.Org/10.32493/Arastirma.V1i1.10061

Dessler. (2010). Manajemen Sumber Daya Manusia. Jakarta. Indeks.

Edy Sutrisno, (2009), "Manajemen Sumber Daya Manusia", Jakarta, Kencana Pernada Media Group

Edy, Sutrisno, (2016), Manajemen Sumber Daya Manusia, Kencana Prenada Media Group, Jakarta.

Ghozali, Imam, (2016), Aplikasi Analis Multivariate Dengan Program IBM SPSS 21, Edisi 2, Universitas Diponegoro, Semarang.

Handoko, T. Hani. (2003). Manajemen. Cetakan Kedelapanbelas. BPFEYogyakarta, Yogyakarta.

Hani, Handoko T. (2008). "Manajemen Personalia dan Sumber Daya Manusia". BPFE : Yogyakarta

Handoko, T. Hani. (2012), “Manajemen Personalia dan Sumber Daya Manusia”. Yogyakarta: BPFE.

Hasibuan, Malayu S.P, (2006), Manajemen Dasar, Pengertian, dan Masalah,Edisi Revisi, Bumi Aksara:Jakarta

Hasibuan, S.P Malayu, (2009). "Manajemen Sumber Daya Manusi", cetakan ke tujuh Penerbit PT Bumi Aksara, Jakarta.

Hasibuan, Malayu S.P, (2016), Manajemen Sumber Daya Manusia. Bumi Aksara, Jakarta.

Husein Umar, (2004), Metode Penelitian Untuk Skripsi Dan Tesis Bisnis, Cet ke 6, Jakarta : PT RajaGrafindo Persada.

Hasibuan Malayu, S.P. (2007). Manajemen Sumber Daya Manusia, cetakan kesembilan, Jakarta : PT Bumi Aksara.

Hasibuan, Malayu S.P. (2009). Manajemen Sumber Daya Manusia (Edisi revisi cetakan ke tiga belas). Jakarta: PT Bumi Aksara

Hasibuan, P.S. Malayu. (2015). Manajemen Sumber Daya Manusia, Penerbit : PT. Bumi Aksara, Jakarta

Hariandja, Marihot Tua Efendi, (2002), Manajemen Sumber Daya Manusia, Grasindo, Jakarta

Ikhsan dan Ishak Kuncoro, Mudrajad. 2003. Metode Riset untuk Bisnis dan Ekonomi. Jakarta : Erlangga

Kadarisman. (2012). Manajemen Kompensasi. Jakarta: PT Raja Grafindo Persada.

Kartono, Kartini. Pemimpin dan Kepemimpinan. Jakarta: PT Raja Grafindo Persada, 2011.

Malayu Hasibuan. (2004). Manajemen Sumber Daya Manusia. Cetakan ke Tujuh, edisi revisi, PT. Bumi Aksara. Jakarta

Mangkunegara, Anwar Prabu. (2000). "Manajemen Sumber Daya Manusia Perusahaan". Remaja Rosdakarya. Bandung.

Mangkunagara, Anwar Prabu. (2002). “Manajemen Sumber Daya Manusia”. Remaja Rosdakarya. Bandung.

Mangkunegara, Anwar Prabu. (2011). "Manajemen Sumber daya Manusia Perusahaan”. Remaja Rosdakarya. Bandung. 
Mangkunegara, Anwar Prabu. (2014). "Evaluasi Kinerja SDM". Bandung: Penerbit Refika Aditama.

Mangkunegara Anwar Prabu, (2014), Manajemen Sumber Daya Manusia Perusahaan, PT. Remaja Rosdakarya, Bandung.

Nasution, Mulia, (2000). Manajemen Personalia Aplikasi Dalam Perusahaan,Djambatan, Jakarta

Ridwan. (2008). Dasar-Dasar Statistika. Bandung : Alfabeta

Riduwan. (2014). Metode \& Teknik Penyusunan Proposal Penelitian. Bandung: Alfabeta.

Rivai, Veithzal. \& Sagala, E.J. (2009). "Manajemen Sumber Daya Manusia untuk Perusahaan”. Jakarta: Rajagrafindo Persada.

Sunardi, D. (2021). Pengaruh Kepemimpinan Dan Motivasi Kerja Terhadap Kinerja Pegawai BBTA3-BPPT Kawasan PUSPIPTEK Setu Tangerang Selatan. Jurnal Arastirma, 1(1), 130140. Https://Doi.Org/10.32493/Arastirma.V1i1.10069

Suwanto, S. (2021). Pengaruh Motivasi Terhadap Kinerja Karyawan Pada PT. Fast Food Indonesia (Kfc) Pondok Indah Plaza, Jakarta Selatan. Jurnal Arastirma, 1(1), 15-21. Https://Doi.Org/10.32493/Arastirma.V1i1.10020 